\title{
Norges fjelde - og de geologiske kendsgerninger
}

Af Peter Japsen, Johan M. Bonow, James A. Chalmers og Erik S. Rasmussen, De nationale geologiske undersøgelser for Danmark og Grønland (GEUS)

Hvorfor der er bjerge i Norge? For at kunne besvare dette tilsyneladende simple spørgsmål, må man først finde ud af, hvornår bjergene blev til bjerge. Er de gamle og skabt af kolliderende kontinenter, eller er de unge og dannet af aktive (men måske dårligt forståede) kræfter i Jordens indre?

Det er ikke så nemt at svare på, som man skulle tro. Der er nemlig forskel på stenenes alder og på topografiens alder. Stenene i de norske fjelde er dannet for længe, længe siden, og deres alder kan nemt bestemmes med moderne laboratoriemetoder, mens det ikke er muligt direkte at bestemme, hvordan en fjeldtop har bevæget sig i forhold til havniveau. Derfor kan der opstå diskussion om, hvorvidt der har eksisteret norske fjelde i hundreder af millioner af år eller måske bare i 10 eller 20 millioner år. Og dermed diskussion om hvorfor der overhovedet findes to kilometer høje fjelde i Skandinavien langs den passive rand af det europæiske kontinent.

Søren B. Nielsen (SBN) argumenterer i et indlæg i Geologisk Nyt 3/07 imod tektonisk landhævning af Skandinavien i neogen tid (de seneste 25 millioner år). Desværre har der indsneget sig så mange fejl, at vi finder det fornødent at fremhæve nogle geologiske og geomorfologiske kendsgerninger.

\section{De norske fjeldes udseende og alder} De vidtstrakte fjeld-viddar (højsletter) og de dybt indskårne fjorde er slående træk ved fjeldene i Norge. Geomorfologer har kortlagt disse viddar og har påvist, at de domineres af en let hældende flade, der ligger i mellem 800 og 1200 meters højde over havniveau, og at der findes rester af yderligere flader over dette niveau. Disse plateauer skiller sig markant ud fra et kuperet relief af mesozoisk alder, der ligger som et hældende plan på et lavere niveau langs højsletternes kanter. Det mesozoiske relief er dannet ved forvitringsprocesser i varmt og fugtigt klima og er blevet beskyttet frem

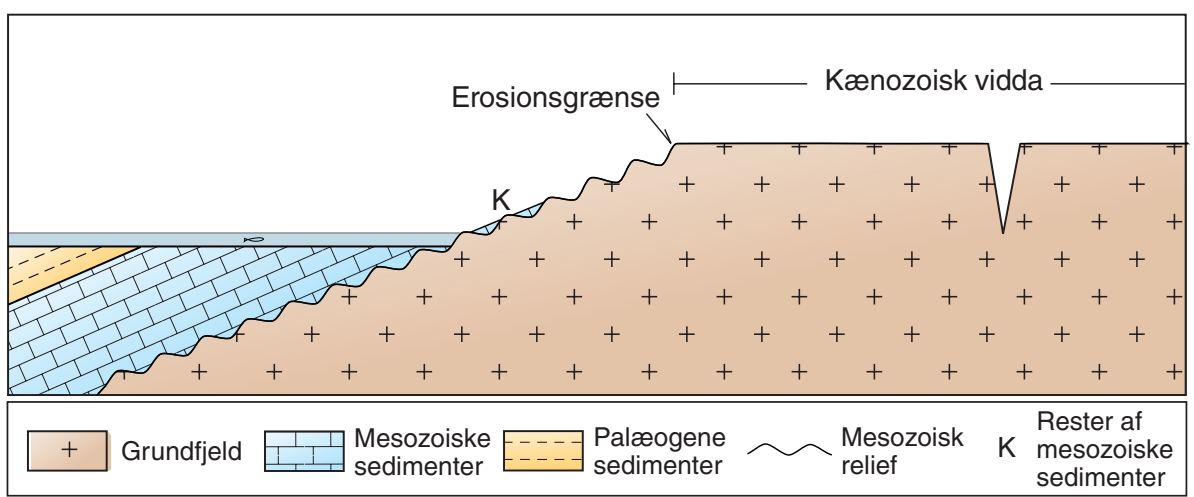

Skitse af den generelle topografi i Sydnorge. De vidtstrakte højsletter (viddar) i de norske fjelde ligger i dag i en højde på mellem 800 og 1.200 m over havniveau (her kun markeret et enkelt niveau). Viddarne blev dannet ved fluvial erosion næer havniveau og tektonisk hæevet til deres nuvœrende højder i løbet af Kœnozoikum. På grund af landhæevningen blev en hæeldende og kuperet mesozoisk flade blottet, efter at beskyttende dceklag var blevet borteroderet. Den kuperede mesozoiske flade afskcres af viddarne, der derfor må vcere dannet senere end det kuperede relief, altså i Kcnozoikum. Fjorde og dale har derefter skåret sig dybt ned $i$ plateauerne, efter at erosionsniveauet er blevet cendret som følge af landhcevningen. (Grafik: Forfatterne)

til i dag af sen-mesozoiske sedimenter. Denne kuperede mesozoiske flade afskæres af viddarne, der derfor må være dannet senere end det kuperede relief, altså i Kænozoikum (figuren ovenfor). Derfor er der ikke videnskabeligt grundlag for SBNs påstande om, at "i mange fjeldområder synes afskårne flade toppe at definere en imaginær flade af større udstrækning” og at disse skulle være "bevarede mesozoiske peneplaner". De vidtstrakte flader er hverken imaginære eller mesozoiske.

Vi mener, at de norske højsletter må være dannet ved erosion styret af en erosionsbasis nær havniveau, da de nuværende norske fjeldområder har ligget nær havet $\mathrm{i}$ det meste af Kænozoikum. Efterfølgende er sletterne hævet til deres nuværende højder, mens de mesozoiske flader er blevet blottet, efter at de beskyttende dæklag er blevet borteroderet. Fjorde og dale har endelig skåret sig dybt ned i plateauerne, efter at erosionsniveauet er blevet ændret som følge af landhævningen.

\section{Klima og tektonik}

SBN skriver, at "det er oplagt at forestille sig”, at øget glaciation i de skandinaviske fjelde på Eocæn-Oligocæn-overgangen (for 35 millioner år siden) kan have forårsaget de store oligocæne sedimentsystemer i bl.a. Skagerrak. Problemet er bare, at man er nødt til at forestille sig disse oligocæne gletschere, da deres eksistens ikke er dokumenteret, mens den første større udbredelse af gletschere i Skandinavien er langt senere (Sen Miocæn, for 6 millioner år siden). Derimod tyder ændringen fra dybt-marint miljø til mere kystnære forhold vest og syd for Skandinavien og den kraftige udbygning af sedimentære systemer på en tektonisk hævning af Skandinavien i starten af Oligocæn. Tilsvarende er der påvist tektoniske bevægelse i Det Norsk-danske Bassin netop på Eocæn-Oligocæn-grænsen. Sandsynligvis var Skandinavien fladt hvis ikke ligefrem overskyllet at hav inden denne hævningsfase. Der er nemlig ingen indikation i sedimenterne på en skandinavisk kyst i Midt Eocæn tid, og forekomsten af omlejrede eocæne sedimenter i det nordlige Finland og Sverige kan tyde på, at det eocæne hav dækkede store dele af Skandinavien.

Yderligere en fase af tektonisk hævning fandt sted i Tidlig Miocæn, hvor der bl.a. skete en markant tilførsel af sedimenter til det danske område på et tidspunkt, hvor klimaet var tempereret til subtropisk. Der er således ingen direkte sammenhæng mellem klima og sedimenttilførsel. Omvendt gælder det, at der i forbindelse med veldokumenterede hævningsfaser altid forekommer stærk 
forøget sedimenttilførsel til Nordsøbassinet i form af delta-komplekser.

\section{Erosion og tiltning af Skandinavien}

Sedimenterne nærmest Skandinavien har været dybere begravet, end de er i dag, og dette forhold viser sig bl.a. i sedimenternes relativt høje lydhastigheder (og relativt lave porøsiteter) (“overbegravelse” i SBNs terminologi). Problemet her er, hvornår de lag, der engang dækkede for eksempel Skrivekridtet på Stevns Klint, er blevet fjernet ved erosion. Igen kan SBN forestille sig ("modellere"), at det er kvartære gletschere, der har spillet den afgørende rolle. Men forestillinger er ikke nok, når begivenhedernes forløb kan aflæses af de sedimentære aflejringer i Nordsøen. Den omfattende erosion i det danske område startede allerede i Tidlig Pliocæn (for ca. 4 millioner år siden) - længe inden det glaciale maksimum der først fandt sted inden for den seneste million år. Erosionen begyndte netop samtidig med udbygning af store sedimentsystemer fra Skandinavien og markant indsynkning i den centrale del af Nordsøen (figuren til højre). Dette er netop blevet påvist i en ny afhandling der blandt andet er baseret på undersøgelse af fissionsspor i apatit fra dybe boringer i Danmark. Disse undersøgelser viser også, at den regionale landhævning og erosion allerede startede i på overgangen mellem Oligocæn og Miocæn (for ca. 25 millioner år siden) i områderne nærmest Norge og Sverige.

Den neogene tektoniske hævning af Skandinavien kulminerede med en gigantisk tiltning af hele den geologiske lagfølge, således at den centrale del af Nordsøen sank yderligere ind, mens områderne nær Skandinavien blev udsat for yderligere landhævning og erosion, således at fx Skrivekridtet på Stevns Klint blev blotlagt. Denne proces fandt sted på overgangen fra Pliocæn til Kvartær (for ca. 2 millioner år siden), og altså i god tid inden den kvartære nedisning for alvor fik betydning. Måske var det ligefrem landhævningen af Skandinavien, der ændrede de klimatiske forhold, sådan at fjeldgletchere kunne udvikle sig til en sammenhængende indlandsis? Starten af den omfattende borterodering af sedimentære dæklag må i alle tilfælde skyldes tektonisk landhævning og ikke glacial erosion.

\section{Fjeldtoppe og skorperødder}

Årsagen til, at SBN prøver at eliminere al dokumentation af tektoniske bevægelser i Skandinavien i Kænozoikum, må være, at den ikke passer med hans forestilling om, at de norske fjelde (det vil sige topografien) har eksisteret siden den kaledonske foldning i Silur, dvs. for 443-417 mio. år siden. Ifølge SBN skyldes de norske fjeldes nuværende højder, at de har en dyb rod, og at roden har eksisteret siden den kaledonske pladekollisionen. Problemet med denne hypotese er, at det længe har været kendt, at

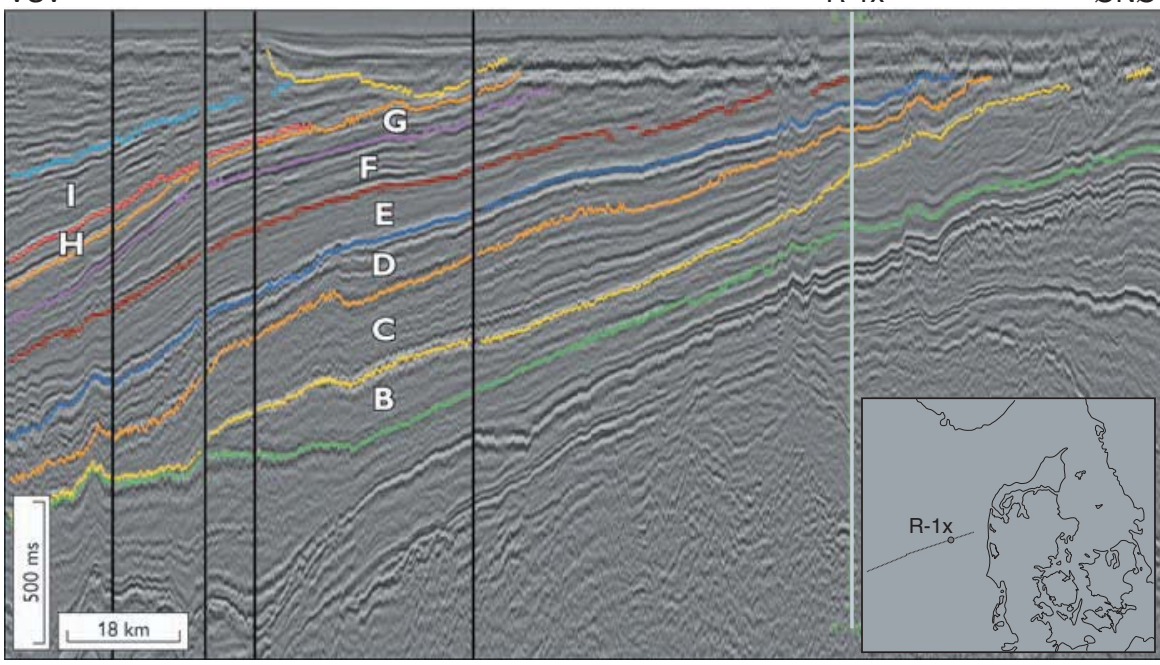

Seismisk sektion fra Nordsøen der viser, at den miocœene lagpakke (sekvenserne B til I) er tiltet i det centrale og det østlige Nordsøbassin. Bemcerk den markante hceldning af de mioccene deltakomplekser i den østlige del af sekvens B og vest for bogstavet " $F$ " $i$ sekvens F. Deltafladerne hcelder 10 gange mere end i deltaer, som dannes i dag, og derfor må hele lagpakken vare tiltet efter aflejringen. Detaljerede sedimentologiske undersøgelser viser, at der må have været betydelige miocæene magtigheder ind over Jylland. Undersøgelser af sedimenternes fysiske egenskaber i R-1 boringen viser, at de øverste ca. $400 \mathrm{~m}$ af den miocœene sekvens er blevet borteroderet i overenstemmelse med den markante afskcring af lagpakken, som ses på figuren. Netop publicerede undersøgelser viser, at denne regionale erosion startede i Tidlig Pliocæen (for ca. 4 millioner år siden) og dermed lange inden den kvartcere nedisning. (Grafik: Forfatterne)

der ikke er nogen rod under Norge. Grænsen mellem Jordens skorpe og kappe (Moho) ligger i en dybde af $40 \mathrm{~km}$ under det meste af Norge, bortset fra et smalt område under Oslograven, hvor Moho-dybden er ca. 30 km. Dybden til Moho øges gradvist mod øst under Sverige og er mere end $50 \mathrm{~km}$ flere steder under Østersøen og Finland. Så ud fra isostasi-hypotesen skulle der være højere bjerge i Finland end i Norge. Det er der som bekendt ikke. SBN henviser til nye undersøgelser af skorpetykkelsen i Sydnorge, men for os at se bekræfter disse undersøgelser kun det generelle billede af, at skorpen i det fennoskandiske område er omkring 40-55 $\mathrm{km}$ tyk, og at der ikke findes nogen rod under de norske fjelde.

Der har været flere forsøg på at forklare, hvorfor der er bjerge i Norge uden en kompenserende rod, $\mathrm{fx}$ variationer $\mathrm{i}$ både densitet og styrke i den nedre skorpe, men der er endnu ikke nået en tilfredsstillende forklaring. Men uanset hvordan man kan tolke forholdene i Jordens indre, må en teori om, hvorfor der er bjerge i Norge, nødvendigvis kunne forklare de geologiske observationer på Jordens overflade.

\section{Observationer og hypoteser}

Der er således en mængde observationer, der tyder på tektoniske bevægelser af Skandinavien i Kænozoikum: pludselig udbygning af sedimenter i Oligocæn, Miocæn og Pliocæn, erosion af områderne langs Skandinavien i Miocæn og Pliocæn og tiltning af den sedimentære lagpakke i Nordsøbassinet i Pliocæn samt kilometer-skala hævning af store land-områder i Sydnorge i Kænozoikum. Disse bevægelser kan imidlertid ikke nemt forklares ud fra teorien om pladetektonik, fordi der er tale om en passiv kontinentalrand - langs Norge er der hverken kollision (Himalaya) eller subduktion (Andesbjergene). Dermed bliver det klart, at der ikke findes nogen etableret teori om neogen hævning af Skandinavien. Tværtimod er der tale om en teori i sin vorden, om fremlæggelse af observationer der ikke er i overensstemmelse med gængse forestillinger. 
Afslutningsvis vil vi påpege, at det ikke fører nogen steder hen at forsøge at tilpasse den geologiske historie til de fysiske processer, som er accepterede (eller lette at modellere) på nuværende tidspunkt. Her begår SBN den samme fundamentale fejltagelse, som mange af hans forgængere har gjort. Fx beregnede Lord Kelvin, at Jorden måtte være mindre end 20 millioner år gammel, fordi kemiske processer i solen ikke kunne have brændt i længere tid, og fordi atomare processer ikke var kendt, mens Lord Kelvin levede. Tilsvarende mente mange geofysikere i det 20. århundrede, at kontinenterne ikke kunne bevæge sig, fordi disse forskere ikke kunne forestille sig de processer i jordens indre, som vi i dag har kendskab til. Vi mener, at de geologiske og geomorfologiske kendsgerninger må være udgangspunktet for en ny teori, der kan forklare de tektoniske bevægelser i Skandinavien.

\section{Referencer:}

Fenner, J. 1988. Occurrences of pre-Qua- ternary diatoms in Scandinavia reconsidered. Meyniana 40, 133-144.

Jansen, E. \& Sjøholm, J. 1991. Reconstruction og glaciation over the past $6 \mathrm{Myr}$ from ice-borne deposits in the Norwegian Sea. Nature 349, 600-603.

Japsen, P., Green, P.F., Nielsen, L.H., Rasmussen, E.S. \& Bidstrup, T. in press. Mesozoic-Cenozoic exhumation in the eastern North Sea Basin: a multi-disciplinary study based on palaeo-thermal, palaeo-burial, stratigraphic and seismic data. Basin Research.

Kinck, J.J., Husebye, E.S. \& Larsson, F.R. 1993. The Moho depth distribution in Fennoscandia and the regional tectonic evolution from Archean to Permian times. Precambrian Research 64, 23-51.

Lidmar-Bergström, K., Näslund, J-O., Ebert, K., Neubeck, T. \& Bonow, J.M.
2007. Cenozoic landscape development on the passive margin of northern Scandinavia, Norwegian Journal of Geology 87, 181-196.

Olesen, O., Dehs, J.F., Ebbing, J., Henriksen, H., Kihe, O. \& Lundin, E. 2007. Aeromagnetic mapping of deep-weathered fracture zones in the Oslo Region - a new tool for improved planning of tunnels. Norwegian Journal of Geology 87, 253-267.

Rasmussen, E.S., Dybkjær, K. \& Piasecki, S. 2006. Neogene fluvial and nearshore marine deposits of the Salten section, central Jylland, Denmark, DGF Bulletin 53, 23-37.

Svenningsen, L., N. Balling, N., Jacobsen, B. H. Kind, R., Wylegalla, K. \& Schweitzer, J. 2007. Crustal root beneath the highlands of southern Norway resolved by teleseismic receiver functions. Geophysical Journal International 170, 1129-1138. 